\title{
Bio-preparation of cotton fabrics
}

\author{
Tzanko Tzanova ${ }^{\mathrm{a}}$, Margarita Calafell ${ }^{\mathrm{b}}$, Georg M. Guebitz ${ }^{\mathrm{c}}$, Artur Cavaco-Paulo ${ }^{\mathrm{a}, *}$ \\ ${ }^{a}$ University of Minho, Textile Engineering Department, 4800 Guimaraes, Portugal \\ ${ }^{\mathrm{b}}$ ETSEIT-UPC, Terrassa, Barcelona, Spain \\ ${ }^{\mathrm{c}}$ Graz University of Technology, Institute of Microbiology, Graz, Austria
}

Received 24 February 2001; received in revised form 9 May 2001; accepted 4 June 2001

\begin{abstract}
This study attempted to introduce the bio-processes in the conventional scouring and bleaching preparation of cotton. The scouring with two types of pectinases, acting under acidic and alkaline conditions respectively, was as efficient as the chemical process in terms of obtained adequate water absorbency of the fabrics. The necessity of surfactants application in scouring was outlined. Bleaching of the fabrics was performed with hydrogen peroxide, which was enzymatically produced by glucose oxidase during oxidation of glucose. The aeration plays an important role in the enhancement of the enzyme reaction, so that the quantity of generated peroxide is sufficient to overcome the stabilizing effect of the glucose and protein in the subsequent bleaching. A closed-loop process reusing starch containing desizing baths in a single step scouring/bleaching operation with enzyme-generated peroxide was performed. (C) 2001 Elsevier Science Inc. All rights reserved.
\end{abstract}

\section{Introduction}

The processing of raw cotton in order to improve its performance in further finishing stages consists of three consecutive steps: desizing, scouring and bleaching. The scouring of the cotton fabrics is a process, which aims to improve the absorbency and the whiteness of textile materials, removing from the fibres the non-cellulosic natural matter, i.e. fats, waxes, pectines and proteins $[1,2]$. Waxy materials and pectins are responsible for the hydrophobic properties of the raw cotton [3]. The efficiency of the scouring process is directly related to the success of the subsequent wet processing operations such as bleaching, dyeing, mercerising, and finishing [4]. Traditionally, this preparation process was performed in alkaline medium at boiling temperature. Alkaline scouring consumes large quantities of alkali and requires an extensive rinsing process that loads the washing effluent with environmentally harmful chemicals. On the other hand cellulose is susceptible to oxidation damage under these treatment conditions [5], which might result in decreased tensile strength of the fabrics. Alkaline scouring may also cause fabric shrinkage and changes in physico-mechanical properties of fabrics, e.g. their handle

* Corresponding author. Tel.: +351-253-510280; fax: +351-253510293.

E-mail address: artur@det.uminho.pt (A. Cavaco-Paulo).
[2]. Another chemical approach for scouring is the extraction with non-polar organic solvent in closed systems [5,6], which removes entirely the waxes, but all the pectin is left.

Several attempts have been made to replace the conventional alkaline boiling with enzymatic systems working at milder conditions. Different individual enzymes and their mixtures were studied-pectinases, cellulases, proteases and lipases [4,7-11]. Pectinases appear to be the most suitable enzymes for this purpose, being capable of depolymerising the pectin, breaking it down to low molecular watersoluble oligomers [12], and thereby improving the absorbency of the textile material, without causing cellulose destruction. Cellulases evaluated for the same application provoked weight, and strength losses [3,7].

The next step, following scouring in textile processing is the bleaching process. The greyness of cotton is due to the natural pigments and matter present in the fibres. The most common bleaching agent nowadays is hydrogen peroxide, which is dosed in excess to the fibres. Alternatively, the peroxide could be produced in situ by enzymatic system glucose oxidase/glucose [13]. Glucose oxidases generate hydrogen peroxide in the presence of oxygen in aqueous solutions, using glucose as substrate. Problems have been reported concerning the maximum bleaching power of the peroxide. The substrate for glucose oxidase (glucose) in this process was coming from enzymatic desizing with amylases. Similar systems were used for bleaching purposes in 
detergent compositions, to produce controlled rates of hydrogen peroxide $[14,15]$. The gluconic acid produced in the enzyme reaction acts as a chelator for metal ions. However, there is still no bleaching process based on enzymatic peroxide generation, which has found industrial application. The implementation of enzymatic systems in the preparation of cotton is advantageous in terms of decreased water-, chemicals-, and energy consumption, reuse of desizing waste baths, milder process conditions, and environmentally friendly processes. Hence, the objective of the present research was to develop an enzymatic process for scouring and bleaching of cotton fabrics, based on the use of both acidic and alkaline pectinases, and glucose oxidase.

\section{Materials and methods}

\subsection{Substrate}

In the experiments starch sized or desized, plain-woven $100 \%$ cotton fabric, $120 \mathrm{~g} / \mathrm{m}^{2}$, was used.

\subsection{Enzymatic desizing}

Starch sized fabrics were treated with a commercial amylase (Rapidase L40) $1 \mathrm{~g} /$ liter, $70^{\circ} \mathrm{C}, 60 \mathrm{~min}$, at $\mathrm{pH} 5$ in $0.1 \mathrm{M}$ acetic buffer.

\subsection{Enzymatic scouring}

The fabrics were scoured with two types of pectinases: an alkaline bacterial pectinase-Bioprep 3000L (NOVO Nordisk) $20 \mathrm{APSU} / \mathrm{g}$ cotton, with pectate lyase activity in 0.05 $\mathrm{M}$ phosphate buffer $\mathrm{pH} 8$, at $55^{\circ} \mathrm{C}$ and an acid fungal pectinase-Pect 062L (Biocatalysts) $70 \mathrm{U} / \mathrm{g}$ cotton, with poligalactorunase/pectate lyase activity in $0.1 \mathrm{M}$ acetate buffer $\mathrm{pH} 5$, at $40^{\circ} \mathrm{C}$, for two hours in the presence of $0.1 \%$ non-ionic surfactant Sandozin NIA (Sandoz). The evaluation of the scouring result was performed monitoring the water absorbency and the weight loss of the fabrics as a result of the enzymatic process. Dyeing experiments to evaluate the effect of the scouring were carried out with a cationic dye (C.I. Basic Blue 45), $0.112 \mathrm{~g} /$ liter, $90^{\circ} \mathrm{C}, 30$ min.

\subsection{Fabric water absorbency}

Water absorbency was evaluated according to an AATCC Test Method 39-1980 (Evaluation of Wet-ability [16]). Wetting time less than one second was considered as indication of adequate absorbency of the fabrics [17].

\subsection{Weight loss evaluation}

At the end of the bio-treatment, the fabrics were removed from the liquor, boiled to inactivate the enzyme, washed thoroughly, and dried followed by weight loss determination. The relative humidity factor calculation was adopted for weight loss estimation. Aliquots were dried at $80^{\circ} \mathrm{C}$ for one hour, and then weighted to determine the humidity factor.

$$
\begin{aligned}
& \text { Factor }_{\text {raw }}=\frac{\text { Dried Aliquot Weight }}{\text { Aliquot Weight }} \\
& \text { Factor }_{\text {scoured }}=\frac{\text { Dried Aliquot Weight }}{\text { Aliquot Weight }} \\
& \% \mathrm{WL}= \\
& \underline{\text { Raw Weight } \times \text { Factor }_{\text {raw }}-\text { Scoured Weight } \times \text { Factor }_{\text {scoured }}} \\
& \text { Raw Weight } \times \text { Factor }_{\text {raw }} \\
& \times 100
\end{aligned}
$$

\subsection{Standard scouring process}

Alkaline scouring was carried out at boiling in sodium hydroxide solution $(0.2 \mathrm{M})$ with $0.1 \mathrm{~g} /$ liter of surfactant.

\subsection{Enzymatic production of hydrogen peroxide}

Production of hydrogen peroxide by glucose oxidase (Sigma) and $\mathrm{D}(+)$-Glucose (Merck) proceeded at $\mathrm{pH} 5$ in $0.1 \mathrm{M}$ acetic buffer, and $35^{\circ} \mathrm{C}$, with aeration (5 liters/min) through a glass tube introduced into the solution, at constant stirring, until sufficient level of peroxide concentration was reached. Hydrogen peroxide concentration was determined by titration with a standard $0.1 \mathrm{~N} \mathrm{KMnO}_{4}$ solution in acidic medium.

\subsection{Standard bleaching process}

The fabrics were bleached following the recipe: silicate $\left(\mathrm{Na}_{2} \mathrm{O} / \mathrm{SiO}_{2}\right)-3.5 \%$ o.w.f. (of weight of fabric), $\mathrm{Na}_{2} \mathrm{CO}_{3} 1 \%$ o.w.f., $\mathrm{NaOH} 1 \%$ o.w.f., and $35 \% \mathrm{H}_{2} \mathrm{O}_{2}-4 \%$ o.w.f., for $1 \mathrm{~h}$ at $90^{\circ} \mathrm{C}$. All the desizing, scouring and bleaching experiments were carried out in triplicate in an Ahiba SpectradyeDatacolor dyeing apparatus at a liquor ratio 20:1. Samples weight was $2.5 \mathrm{~g}$.

\subsection{Fabric whiteness}

The whiteness (CIE whiteness), K/S (coefficient of absorbed light/coefficient of scattered light), and the colour differences $\left(\Delta \mathrm{E}^{*}\right)$ of the bleached fabrics were determined using a reflectance measuring Datacolor apparatus at standard illuminant $\mathrm{D}_{65}$ (LAV/Spec. Incl., $\mathrm{d} / 8, \mathrm{D}_{65} / 10^{\circ}$ ). 
Table 1

Parameters for evaluation of the scouring effect

\begin{tabular}{|c|c|c|c|c|c|}
\hline Enzyme & Medium & $\begin{array}{l}\text { Absorbency } \\
(\%)\end{array}$ & $\begin{array}{l}\text { Weight loss } \\
(\%)\end{array}$ & Whiteness & $\begin{array}{l}\mathrm{K} / \mathrm{S} \text { dyed } \\
\text { fabrics }\end{array}$ \\
\hline Pectinase $62 \mathrm{~L}$ & Distilled water & 240 & 1.8 & - & - \\
\hline \multirow{3}{*}{$\begin{array}{l}\text { Bio Prep } \\
\text { 3000L }\end{array}$} & Distilled water & 243 & 1.7 & & \\
\hline & Sandozin & 2 & 2 & - & - \\
\hline & Distilled water & $>250$ & 1.5 & - & - \\
\hline Pectinase $62 \mathrm{~L}$ & Sandozin & $<1$ & 4.7 & 26.3 & 0.60 \\
\hline $\begin{array}{l}\text { Bio Prep } \\
\text { 3000L }\end{array}$ & Sandozin & $<1$ & 4.6 & 25.5 & 0.57 \\
\hline $\mathrm{NaOH}$ & Sandozin & $<1$ & 6.3 & 34.7 & 0.51 \\
\hline
\end{tabular}

\section{Results and discussion}

\subsection{Bio-scouring}

\subsubsection{Effect of the surfactants in pectinase scouring}

A study on the effect of the surfactants in the bioscouring process of cotton fabrics was carried out. Fabrics were treated for two hours with either acidic or alkaline pectinases at the corresponding conditions with $0.1 \%$ nonionic surfactant added. The non-ionic surfactant have been shown to be compatible with the enzymes [18], and enhanced considerably the scouring effect (Table 1) due to the reduced surface tension of the fibres and easier penetration of the enzymes into fibres micropores and cracks. Afterwards the surfactant maintains the enzyme in the liquid phase, making it available for further catalytic action [18]. Without good wetting of the substrate the scouring effect was insignificant. Thus, the surfactant is a necessary component in the enzymatic composition for scouring and seemed to have a high impact in the removal of waxes and fats, while the enzyme facilitates the removal of the pectic substances.

\subsubsection{Evaluation of the scouring effect}

Both the alkali and acid pectinases were found to be equally efficient in terms of improved absorbency as the conventional alkali scouring. However, the weight loss in the enzymatic process was lower by $25-27 \%$. Lower dosage of the alkaline pectinase (20 APSU/g cotton) in contrast to the acidic enzyme ( $70 \mathrm{U} / \mathrm{g}$ cotton) was required to achieve the desired fabric properties. To estimate the removal of the natural matter from cotton, the fabrics were dyed with a cationic dye, substantive to pectic substances, and proteins [7,19]. All bio-treated samples were slightly dyed (low K/S values), which indicated a decrease in the proteins and pectin content of the fibres. Thus the pectinase treatment resulted in an absorbency and removal of the fibre cuticle comparable to the chemical process.

\subsection{Bio-generation of hydrogen peroxide for bleaching}

\subsubsection{Enzymatic production of hydrogen peroxide}

Various experimental conditions, e.g. enzyme and substrate concentration for the production of peroxide were tested. Aeration was found to be of outstanding importance for the production of hydrogen peroxide, and for identical initial conditions the amount of peroxide produced increased 2-fold (Fig. 1). The enzymatic process reached a plateau (Fig. 1, and 2) probably due to decrease in substrate concentration or inactivation of the enzyme during the time. This flat level was reached faster with higher enzyme concentration, which is related to faster substrate transformation. The same quantity of peroxide might be produced with lower enzyme concentrations, however the process becomes quite time consuming. Both time and cost considerations should be taken into account when choosing the appropriate enzyme concentration.

\subsubsection{Bleaching of bio-scoured fabrics}

Desized cotton fabrics, scoured with two types of pectinases: alkaline, and acidic were bleached $\left(\mathrm{pH} 10-11,90^{\circ} \mathrm{C}\right.$, $60 \mathrm{~min})$ with enzymatically produced peroxide $(0.408 \mathrm{~g} / \mathrm{li}-$ ter after $4 \mathrm{~h}$ enzyme reaction of $22.68 \mathrm{U} / \mathrm{ml} \mathrm{GOX}$ and 20 g/liter Glucose, Fig. 2). The increase in whiteness of the

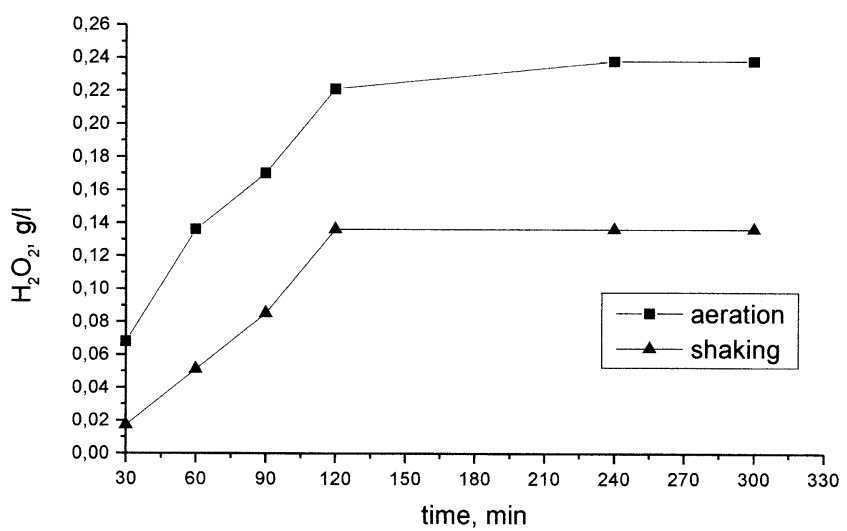

Fig. 1. Peroxide production from $20 \mathrm{~g} /$ liter glucose and $3.78 \mathrm{U} / \mathrm{ml}$ GOX. 


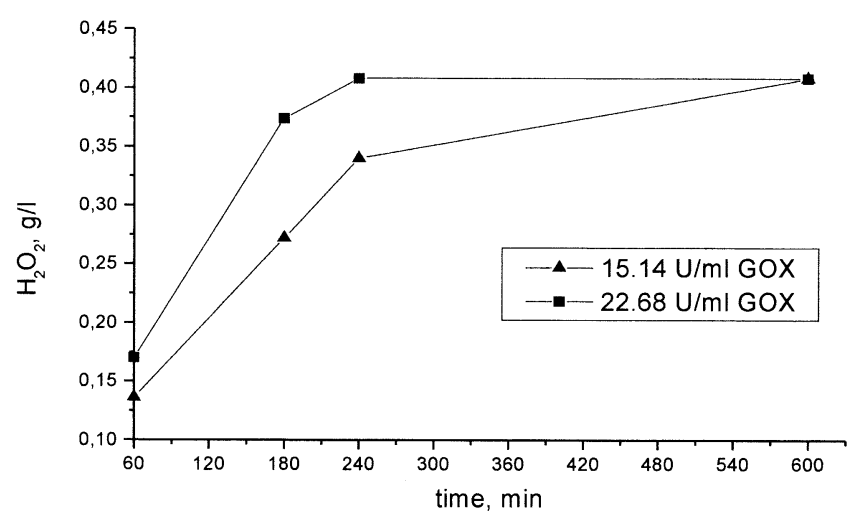

Fig. 2. Peroxide production from $20 \mathrm{~g} /$ liter glucose and respectively 15.14 , and $22.68 \mathrm{U} / \mathrm{ml} \mathrm{GOX}$, with aeration.

alkaline scoured fabrics was larger (with $73 \%$ compared to the initial whiteness of scoured fabric) than for the acid scoured samples (whiteness improvement $65 \%$ ), while both fabrics reached a similar degree of whiteness -66.1 and 66.4 respectively, after the bleaching process. Although the alkaline pectinase scouring itself resulted in lower whiteness than the acidic enzyme treatment (Table 2), it was favorable to the subsequent bleaching process as was previously reported [20]. The results from the bleaching with enzymatically produced peroxide were comparable to the results obtained with a standard bleaching process $(0.17$ $\mathrm{g} /$ liter hydrogen peroxide according to the recipe $-4 \%$ o.w.f., $35 \% \mathrm{H}_{2} \mathrm{O}_{2}$ ), and the colour difference $\left(\Delta \mathrm{E}^{*}\right)$ between the fabrics bleached chemically and with bio-generated peroxide was within 1 CIELab unit.

Surprisingly, the quantity of the enzymatically-produced peroxide needed to achieve the same bleaching effect as in the standard bleaching process was nearly twice higher $(0.408 \mathrm{~g} / \mathrm{liter})$. One possible explanation is that the added glucose protects the cotton from the bleaching action, acting as a substrate for bleaching and oxidation, thereby consuming the peroxide. However, bleaching experiments conducted with glucose concentrations ranging from 5 to 20 $\mathrm{g} /$ liter, and without fabric, showed that the glucose had a stabilizing effect on the hydrogen peroxide, retarding the bleaching process (Fig. 3). When in the bleaching bath there is no glucose (respectively gluconic acid) the peroxide is

Table 2

Whiteness of the bleached fabrics

\begin{tabular}{lll}
\hline & $\begin{array}{l}\text { Alkaline } \\
\text { pectinase } \\
\text { scouring }\end{array}$ & $\begin{array}{l}\text { Acid } \\
\text { pectinase } \\
\text { scouring }\end{array}$ \\
\hline $\begin{array}{l}\text { Whiteness after scouring } \\
\begin{array}{l}\text { Whiteness after std. peroxide } \\
\text { bleaching }\end{array}\end{array}$ & 25.5 & 26.3 \\
$\begin{array}{l}\text { Whiteness after bleaching with bio- } \\
\text { generated peroxide }\end{array}$ & 67.5 & 70.4 \\
$\begin{array}{l}\text { Colour difference between chemically } \\
\text { and enzymatically bleached fabrics }\end{array}$ & 06.1 & 66.4 \\
\hline
\end{tabular}

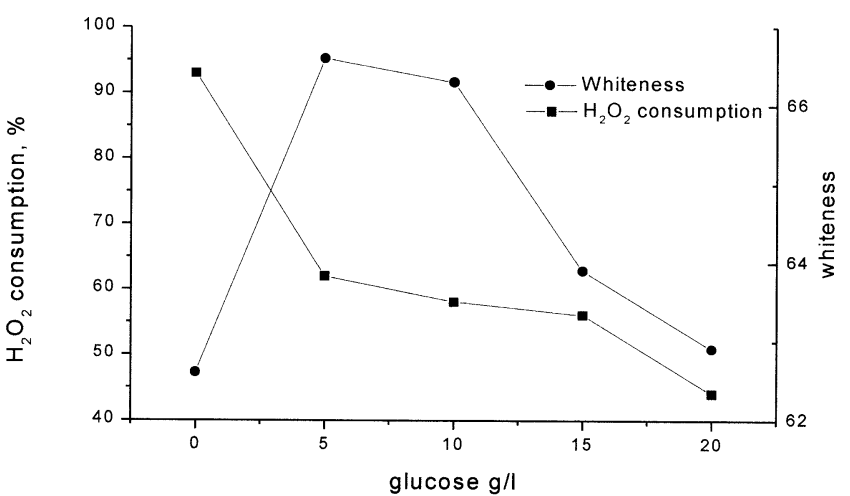

Fig. 3. Peroxide consumption (initial $\mathrm{H}_{2} \mathrm{O}_{2}$ concentration 0.4 g/liter) and bleaching effect in the presence of glucose in the bleaching bath.

degraded too fast without accomplishing its bleaching action. Up to certain concentration the presence of glucose in the bleaching bath improves the whiteness of the bleached fabric. However, further increase in glucose concentration reduced additionally the consumption, and at the same times the bleaching power of the peroxide, where from higher initial peroxide concentrations were needed to ensure an adequate bleaching effect. The effect of the presence of glucose in the bleaching composition on the whiteness of the fabrics depends strongly on the $\mathrm{pH}$ of the bath. At $\mathrm{pH}$ $10-11$, the whiteness was not affected substantially $\left(\Delta \mathrm{E}^{*} \sim\right.$ $0.7)$, but at $\mathrm{pH} 12$ the glucose caramelised, the solution became brownish and imparted colour to the fabric instead of bleaching it (results not shown). On the other hand at $\mathrm{pH}$ 12 the hydrogen peroxide loses its bleaching power, and decomposes into oxygen and water.

A series of experiments were carried out to study the effect of the presence of protein in the bleaching solution on peroxide consumption and whiteness of the bleached fabrics. The results indicated retarded decomposition of the peroxide with the increase of protein concentration, which was reflected in decreased whiteness (Fig. 4). However, the absence of protein in the bleaching composition resulted in fast and ineffective consumption of the peroxide. On the other hand with the increase of the bleaching process tem-

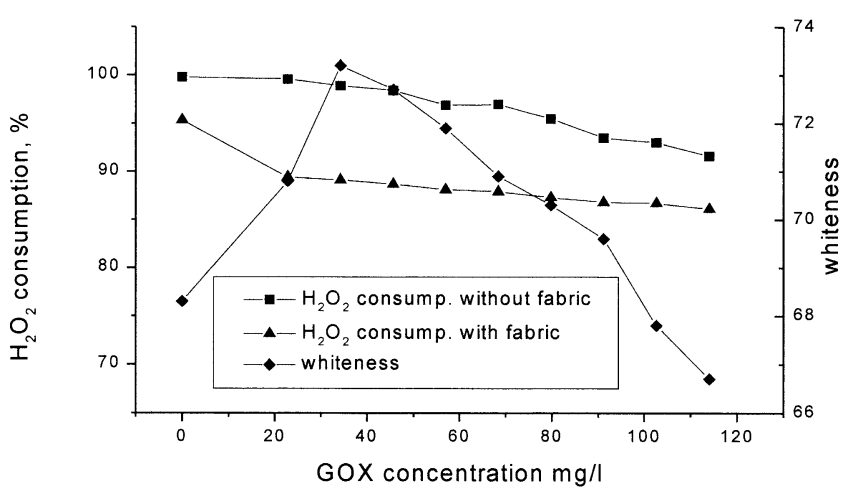

Fig. 4. Peroxide consumption (initial $\mathrm{H}_{2} \mathrm{O}_{2}$ concentration $0.4 \mathrm{~g} /$ /iter) and bleaching effect in the presence of protein in the bleaching bath. 
Table 3

Whiteness of fabrics, bleached with enzymatically produced hydrogen peroxide, using desizing baths as an additional source for glucose

\begin{tabular}{lll}
\hline & $\begin{array}{l}\text { Desized } \\
\text { fabrics }\end{array}$ & $\begin{array}{l}\text { Acidic pectinase } \\
\text { scoured fabric }\end{array}$ \\
\hline $\begin{array}{l}\text { Whiteness after std. peroxide } \\
\text { bleaching }\end{array}$ & 62.3 & 70.5 \\
$\begin{array}{l}\text { Whiteness after bleaching } \\
\text { with bio-generated }\end{array}$ & 52.2 & 64.7 \\
$\begin{array}{l}\text { peroxide } \\
\text { Colour difference between } \\
\text { chemically and } \\
\text { enzymatically bleached } \\
\text { fabrics }\end{array}$ & 1.9 & 1.2 \\
\hline
\end{tabular}

perature the protein denaturates and transition from globular to random coil, open structure occured. The open enzyme structure facilitates some possible hydrophobic fabric-enzyme interaction, and deposition of the denaturated protein on fabric surface, thereby protecting it by the bleaching action of the peroxide.

\subsection{Reuse of enzymatic desizing baths for production of hydrogen peroxide and subsequent one-step scouring/ bleaching process}

Raw cotton woven fabrics were desized with amylase (Rapidase L40), and glucose/GOX enzymatic system (20 $\mathrm{g} /$ liter glucose, $15.14 \mathrm{U} / \mathrm{ml}$ GOX) was added to the desizing liquor. The solution was stirred and aerated until sufficient level of peroxide production was reached. The enzymatically produced hydrogen peroxide was activated setting the $\mathrm{pH}$ to $10-11$, and the fabrics were treated at $90^{\circ} \mathrm{C}$ for 60 min, thereby performing the scouring and bleaching process in a single step. The combined scouring and bleaching process is suitable when a very high whiteness is not needed. Advantageously, the entire process was carried out in the residual desizing bath, and no fresh water was added, enabling considerable water savings. The desizing bath was a source for substrate (glucose) in the enzymatic peroxide generation as used for bleaching of the previously bioscoured (acid pectinase Pect 062L) fabrics as well. The previous bio-scouring, e.g. the separation of the scouring and bleaching processes, improved the whiteness of the fabrics (Table 3). The single step procedure was not able to reach the whiteness of the fabric treated with the conventional bleaching process, probably due to contamination of the reused desizing/scouring/bleaching bath, and decreased bleaching power of the peroxide.

\section{Conclusions}

In this research the scouring efficiency of two types of pectinases-acidic and alkaline, was investigated. The bioscoured fabrics were bleached afterwards with enzymatical- ly-produced hydrogen peroxide. A single step scouring/ bleaching process, reusing residual desizing bath, was developed as well. The alkali pectinase had similar performance to the acidic enzyme, however in lower concentrations, which is beneficial from an economic point of view. Surfactants were necessary to achieve adequate removal of the fibre matter, and to render the textile structure accessible for further finishing treatment. The advantages coming from the bio-scouring operation could be increased provided an appropriate enzymatic, hydrogen peroxide generating process for bleaching being available. In the enzymatic production of hydrogen peroxide several important features were outlined: the oxygen aeration was of outstanding importance for the production of peroxide, and increased 2-fold the activity of the glucose oxidase; the quantity of the enzymatically produced peroxide needed was 2 -fold higher than in the standard bleaching, to reach the same degree of whiteness due to the stabilisation effect of the glucose and protein present in the bleaching bath. Best activation of the enzymatically-produced peroxide was achieved at high temperature $\left(90^{\circ} \mathrm{C}\right)$ and alkaline medium. However at $\mathrm{pH}>$ 11.5 and high temperature the glucose caramelised and imparted colour to the fabric, instead of the expected bleaching effect. Reusing the desizing baths as an additional source for glucose in the enzymatic peroxide generation, and performing a single step scouring and bleaching process might realise significant water savings, though the process has to be further improved. Summarising our results a closed-loop enzymatic desizing-scouring-bleaching process seems to be possible and economically attractive.

\section{References}

[1] Batra SH. Handbook of Fiber Science and Technology, vol. IV, M. Lewin and E.M. Pearce, Eds., Marcel Dekker, NY, 1985.

[2] Etters JN, Husain PA, Lange NK. Alkaline Pectinase: An EcoFriendly Approach to Cotton Preparation. Textile Asia 1999;5:83-5.

[3] Freytag R, Dinze JJ. Fundamentals and Preparation Part A, Handbook of Fiber Science and technology:Vol I, Chemical Porcessing of Fibers and Fabrics, edited by Menachem Lewin and Stephan B. Sello, Marcel Dekker, N. 1983;111.

[4] Hsieh YL, Thompson J, Miller A. Water Wetting and Retention Properties of Cotton Assemblies as Affected by Alkaline and Bleaching Treatments. Textile Res J 1996;66:456-64.

[5] Buschle-Diller G, El Mogahzy Y, Inglesby MK, Zeronian SH. Effects of Scouring with Enzymes, Organic Solvents, and Caustic Soda on the Properties of Hydrogen Peroxide Bleached Cotton Yarn. Textile Res J 1998;68:920-9.

[6] Hull RB. Weighting the Alternatives of Scouring Technology. Am. Textiles R/B Ed, 1980:41-3.

[7] Yonghua Li, Hardin I. Enzymatic Scouring of Cotton: Effect on Structure and Properties. Text Chem Color 1997;29:71-6.

[8] Robner U. Enzymatic Degradation of Impurities in Cotton. Melliand Textilberichte 1993;74:63.

[9] Hartzell-Lawson M, Durrant S. Improving the Efficiency of Pectinase Scouring With Agitation to Improve Cotton Fabric Wettability, Book of Papers, International AATCC Conference, Philadelphia, US 1998: 310-18. 
[10] Buchert J, Pere J, Puolakka A, Nousiainen P. Enzymatic Scouring of Cotton, Book of Papers, International AATCC Conference, Philadelphia, US 1998:493-9.

[11] Calafell M, Torrades F, Rodo J, Cayuela D, Blanco A, Pastor FIJ, Puig A, Gacen J. Descrudado enzimático del algodón. Una aproximación a las tecnologias límpias. Revista de Química Textil 1998; 139:83-9.

[12] McNeil M, Darvill AG, Fry SC, Albertsheim P. Structure and Function of the Primary Cell Walls of Plants. Ann Rev Biochem 1984; 53:625-63.

[13] Schacht H, Kesting W, Schollmeyer E. Perspectiven Enzymatischer Prozesse in der Textilveredlung. Textilveredlung 1995;30:237-43.

[14] Van der Helm. Enzymatic Bleach Composition. WO Patent 98/ 1998: 28400.
[15] Pramod K. Liquid laundry detergents containing stabilized glucose/ glucose oxidase as $\mathrm{H}_{2} \mathrm{O}_{2}$ generation system. US Patent 52 1994: 88746.

[16] AATCC Technical Manual.;1980;55:286.

[17] Hsieh Y, Cram L. Proteases as Scouring Agents for Cotton. Textile Res J 1999;69:590-7.

[18] Yonghua Li, Hardin I. Enzymatic Scouring of Cotton -Surfactants, Agitation, and Selection of Enzymes. Text Chem Color 1998;30:23-9.

[19] Traore M, Buschle-Diller G. Environmentally Friendly Scouring Processes, Book of Papers, International AATCC Conference, Charlotte, US 1999:183-9.

[20] Lange N, Liu J, Husain P, Condon B. Biopreparation of Cotton, Book of Papers, International AATCC Conference, Philadelphia, US 1998: 463-71. 